\title{
Coping with and Adapting to Climate and Non-Climate Stressors Within the Small-Scale Farming, Fishing and Seaweed Growing Sectors, Zanzibar
}

\author{
Makame Omar Makame \\ The State University of Zanzibar \\ Sheona Shackleton \\ University of Cape Town \\ walter Leal Filho ( $\nabla$ walter.leal2@haw-hamburg.de ) \\ Hochschule fur Angewandte Wissenschaften Hamburg https://orcid.org/0000-0002-1241-5225
}

\section{Research Article}

Keywords: Adaptation, barriers, climate change, small island states, coastal communities, coping responses, livelihoods, fishing, farming, seaweed growing

Posted Date: December 14th, 2021

DOI: https://doi.org/10.21203/rs.3.rs-1083174/v1

License: (1) This work is licensed under a Creative Commons Attribution 4.0 International License. Read

Full License 


\section{Abstract}

The Eastern African region is witnessing changes in climate conditions and rising sea levels due to the influences of global warming interacting with weather phenomenon such as El Nino and La Nina. These trends, as well as more intense extreme weather events, highlight the urgent need for appropriate adaptation responses at both the national and local level. This is especially the case for the numerous small islands of the region that are particularly vulnerable to climate change. This paper reports on a study that examined coping and adaptation responses to climate and non-climate stressors amongst coastal communities on two Zanzibar islands (Pemba and Unguja) in Tanzania. The study focused on three of the primary livelihood activities on the islands, namely, seaweed growing, fishing, and crop and livestock farming. Using mainly survey data, we explored the responses of farmers, fishermen, and seaweed growers to multiple shocks and stressors. We further investigated responses that were discontinued for various reasons, as well as any barriers to adaptation encountered by these communities. We found that coastal communities in both Kiuyu Mbuyuni, Pemba and Matemwe, Unguja face a range of interrelated shocks and stressors linked to their livelihood activities, some of which they were able to respond to primarily through coping strategies. However, their attempts to adapt in the longer term as well as to venture outside their traditional activities were constrained by several barriers. Some of these barriers operate beyond the individual and community capability to overcome, whilst others - like social and cultural barriers - can be addressed at the local level but need a concerted effort and political will. We draw the findings together into a conceptual framework to help unpack the implications these hold for coastal communities on the two islands. We then suggest ways to build resilience in local livelihoods and overcome barriers to climate change adaptation in the future.

\section{Introduction}

Throughout human history, individuals and local communities have coped with and adapted to resource and climate irregularities (Adger et al. 2009; Orlove, 2005). Various empirical studies, including the latest IPCC reports AR5 and AR6 (WGI), show that current and future climate change impacts on fishing and agriculture can be significantly minimised through adaptation and by taking advantage of the opportunities offered by a changing climate. Understanding how farmers and fishers cope with and adapt to climate change within the context of other stressors is crucial in order to develop intervention options that could assist them in graduating from vulnerability (Below et al. 2012) and building resilience to future changes in climate. To understand adaptation responses (processes and actions) at different levels of decision-making (e.g. individual, group and institution), various scholars working in climate change adaptation have tried to classify adaptation in various ways. For example, in terms of duration, adaptation can be either anticipatory (also called strategic) or reactive (also known as tactical). Tactical adaptations are short-term responses (the same as coping strategies) that are meant to solve the problem at a single point in time, whilst strategic adaptation is a long-term strategy that can sustainably solve the problem in the future (Belliveau et al. 2006). For instance, planting and conserving fodder for livestock to be used during drought would be strategically adaptive, while moving livestock herds outside the depleted grazing land to search for pastures in each and every dry spell could be called a reactive or tactical adaptation. Adaptation can also be either planned (externally facilitated) or autonomous (taken up by individuals and communities themselves) (Jones and 
Boyd, 2011; Belleveau et al. 2006; Grothmann and Patt, 2005; Orlove, 2005), and it can be categorised according to the actors involved, such as private or public adaptation efforts.

Furthermore, adaptation involves mental preparation (Grothmann and Patt, 2005; Kuruppu and Liverman, 2011) and a belief that it is possible to mitigate climate risks (Blennow and Persson, 2009); it also involves utilisation of resources (Thornton and Manasfi, 2010). Indeed, the ability of any decision unit to adapt is influenced to a large extent by existing capital stocks or livelihood assets and access to these (Adger, 2003; Islam et al. 2011). Adaptation of a community or an individual in response to climate variability and change is a dynamic process that involves a set of diverse and intersecting factors that may take place autonomously or through planning (Thornton and Manasfi, 2010), especially in an African context (Leal Filho et al 2021). For example, a belief in risks alone may not be enough to motivate adaptation if there are no means to do this. $A$ fisherman would not shift from shore fishing to vessel fishing if there were no resources to acquire a vessel or boat, even if he perceived a decline in the fish catch in the area close to the shore.

The recognition that there are various factors that may hinder adaptation has resulted in, especially during the second half of the last decade, a number of researchers questioning why some people adapt and others do not, even when they may have the technological, institutional and human capital means to do so. Responding to this question, various studies have revealed that individual motivation to adapt is influenced by a wide range of factors, ranging from financial and social capabilities to cognitive and psychological reasons (Grothmann and Patt, 2005; Adger et al. 2009; Gifford, 2011). These factors are collectively termed as the 'limits and barriers to adaptation' (Adger et al. 2009; Jones, 2010; Jones and Boyd, 2011; Nielsen and Reenberg, 2010). Limits are defined as obstacles that constitute thresholds beyond which existing activities, land uses, ecosystems, species, sustenance, or the system state cannot be maintained, not even in a modified fashion (Nielsen and Reenberg, 2010 cited in Moser and Ekstrom, 2010: 1). Barriers, on the other hand, are defined as obstacles that can be overcome with a concerted effort, creative management, change of thinking, prioritisation, and related shifts in resources, land uses, and institutions (Moser and Ekstrom, 2010:2).

In examining hinderances to adaptation in western Nepal, Jones and Boyd (2011) identified three main categories of barriers: namely, social, natural, and human-informational. Here, we focus on social and humaninformational barriers, as this study centred on the human side of coupled human-environmental systems. The lack of attention to these types of barriers was highlighted by Shackleton et al. (2015) in a review of barriers to adaptation in Sub-Saharan Africa (SSA), where they mention that hidden and under-acknowledged political, social, and psychological barriers were rarely written about. Social barriers are endogenous to societies and related to individual and social factors that may hold back or delay the decision of an individual or community to adapt to climate change. These include cognitive factors, institutions, individual characteristics, perceptions of risk, culture and beliefs, and ethics (Jones and Boyd, 2011; Nielsen and Reenberg, 2010; Adger et al. 2009). For example, the unwillingness to deviate from culture has constrained local people in northern Burkina Faso from diversifying their livelihoods through actions like migration to cope with declining rainfall (Nielsen and Reenberg, 2010), while in Nepal, discrimination through the caste system has reduced access to important assets for adaptation amongst the discriminated segment of the population (Jones and Boyd, 2011). In Sub-Saharan Africa, agro-pastoralists' cultural attachment to livestock can hinder appropriate responses by deterring livestock disinvestment during, for example, drought periods or 
discouraging substitution of livestock type or breed with more resilient options (Shackleton et al. 2015; Muchuru and Nhamo, 2017).

Human-informational barriers include the financial costs of adaptation, development, diffusion, and adoption of technologies, lack of or low levels of information amongst policy and decision makers, and uncertainty regarding climate change (Jones and Boyd 2011; Jones, 2010; Huang et al. 2011; Patt and Gwata, 2002). For example, in the Pampas belt of Argentina, Barros (2009) found that inadequate awareness regarding rainfall and precipitation trends, attributed to the slow nature of seasonal and decadal variability, acted as a barrier for the farmers to adapt. With regard to fishing, a study by Nagy et al. (2009) showed that fishermen migration (seasonal relocation of fishing sites and spontaneous) as a coping strategy for El Niño-Southern Oscillation (ENSO) events and other trends is constrained by climate uncertainty. Using the sustainable livelihoods framework (SLF), Osman-Elasha et al. (2009) identified various barriers that constrain adaptation in the north Kordofan state of South Sudan. These included conflicts over resources, lack of financial resources, civil war, social conflicts, and brain drain, amongst others. Shackleton et al. (2015) in their review of barriers to adaptation in SSA revealed that climate uncertainty, high levels of variability, a lack of information on the frequency and intensity of extreme events, and poor predictive capacity at a local scale were often cited as informational barriers to adaptation. At the local level, it may be challenging for people to detect trends in climate amid short-term fluctuations, as weather variability has always been part of natural resource dependent communities' experiences and they may underestimate the severity of changing conditions. This can result in cognitive barriers to adaptation. However, evidence also illustrates that most people who depend on ecosystem services for their livelihoods do perceive changes in weather patterns and acknowledge the associated risks, although the causes of the changes are not always known or might be attributed to God's or Allah's doing, supernatural forces, or punishment for societal misdemeanour (Shackleton et al. 2015).

The foregoing discussion demonstrates the fact that the motivation and decision of an individual, household, or community to adapt to climate change is influenced not only by their adaptive capacity (e.g. access to technologies, economies, knowledge and livelihood assets) but also by social, human-informational and cognitive factors (Grothmann and Patt, 2005; Adger et al. 2009; Gifford, 2011). This is mainly because social, cultural, informational, and cognitive factors interact with other factors such as technology, capital stocks, and access to facilitate adaptation processes and actions. It can be argued, therefore, that the degree to which an impediment to adaptation becomes either a limit or a barrier will vary between individuals, across different livelihood activities, and within communities. Vulnerability levels between farmers, seaweed growers, and fishermen will thus vary, not only due to different climate risks in their sectors, but also based on their capacity as an individual, community, or society to overcome these barriers through enough political will, social support, assets and resources, social learning, and effort.

In this paper we firstly examine the range of responses to climate and related non-climate stressors by individuals within three important local livelihood sectors in Zanzibar, i.e., farming, fishing and seaweed growing, as well as outside these sectors through the diversification of livelihood activities. We classify the responses according to the adaptation categories outlined above. Secondly, we determine whether any of the response options employed were discontinued and the reasons for this. Following this, we consider the barriers behind i) discontinuance of responses, ii) the adoption of possible options not employed, and iii) longer-term adaptation and transformation that can build resilience to future climate risks alongside non- 
climate stressors. As part of the discussion, we developed an integrated conceptual framework to understand the linkages between all of the above elements and used this to consider the implications of the results for the resilience of east coastal communities in Zanzibar, as well as some solutions going forward. We end with a conclusion.

\section{Methods}

\subsection{Study areas}

This study was carried out in two wards (shehia) located in the northeast corner of each of the two major islands of Zanzibar (Fig. 1), namely, Kiuyu Mbuyuni on Pemba Island and Matemwe on Unguja Island. The east coast is known for its unreliable rainfall, poor coral rag soils, and high levels of poverty (Walsh, 2009). Fishing, seaweed growing, crop cultivation, and livestock keeping are the main livelihood activities in these areas. However, all of these activities are either controlled or influenced by the climate and sea level. Throughout its history, Zanzibar has experienced periods of intense storms and extreme temperatures and rainfall, which threatened the commercial farming of cloves and coconut and fishing activities (Spinage, 2012). In the past two decades, Zanzibar has experienced a high frequency of dry spells and localised food shortages (Said, 2011; Walsh, 2009), stronger winds and heat waves than previously recorded (Watkis et al. 2012), and coral reef bleaching attributed to the El Niño event of 1997/1998 (Payet and Obura, 2004). In 2019, Tanzania's minimum and maximum temperature were high compared with the annual average. These temperatures made 2019 the fourth warmest year since 1970. The first, second and third warmer years in the series were 2003,2010 and 2005 with a temperature anomaly of $1.2^{\circ} \mathrm{C}, 0.9^{\circ} \mathrm{C}$ and $0.89^{\circ} \mathrm{C}$, respectively (TMA, 2019). Other events have included coastal floods in urban Unguja in 2007 (Mustelin et al. 2010), coastal floods in arable land in Pemba in 2010-2011 (Sultan, 2011), the highest temperature ever recorded $\left(39.4^{\circ} \mathrm{C}\right)$ in February, 2007, and extreme rainfall, such as the event in April, 2005 when 474 mm were recorded in just 24 hours at Zanzibar airport weather station (Mustelin et al. 2010). The last time an extreme rainfall event like this was recorded was in 1942 (Mustelin et al. 2010). Tanzania's average annual total rainfall for 2019 was $1,284 \mathrm{~mm}$, which is higher than the long-term average (1981-2010) rainfall by $256.5 \mathrm{~mm}$ and equivalent to $125 \%$ of the long-term average. This makes 2019 the fourth wettest year on record since 1970 (TMA, 2019). Acknowledging these examples of weather-related events, one can easily argue that the climate in Zanzibar is varying and thus threatening the livelihoods of coastal communities.

With regards to socio-economic characteristics of the studied population, the results from the 2014/15 Household Budget Survey (HBS) show that, for every 100 persons in Zanzibar in the economically active group (aged 15 to 64 years), there were 86 dependent persons. In Micheweni district, Pemba where Kiuyu Mbuyuni is located the dependency ratio stood at $109 \%$ while in North A district, Unguja where Matemwe is located it stood at $91 \%(S M Z, 2016)$. Regarding female-headed households, $22.8 \%$ of the households in Zanzibar are headed by women, in which Michweni district and North A district had $21.9 \%$ and $21.2 \%$ of female-headed households, respectively $(S M Z, 2016)$. Furthermore, concerning literacy, the results of the $2014 / 15$ HBS show that illiteracy is generally higher in rural areas (23.9\%), where both sites are located, than in urban areas $(7.7 \%)$. The food poverty for this reporting period stands at $10.8 \%$. This means that approximately 157,133 people in Zanzibar are living on less than TZS 38,071 a month with large variations 
between urban and rural areas and between Unguja and Pemba districts (SMZ, 2016). For example, food poverty stands at $4.4 \%$ in North district, Unguja where Matemwe is located, while in Micheweni district, Pemba where Kiuyu Mbuyuni is located it stands at 32.6\% (SMZ, 2016).

Studies also highlight the low access and ownership of many important assets such as land, a good house, home appliances, and fishing and farming equipment that could assist communities in enhancing their resilience to currently observed and future changes in climate (SMZ, 2016; Makame, 2013).

\subsection{Data collection and analysis}

This study is part of a larger project that combines data from various sources. A major source of information for this particular study was a coping and adaptation survey that consisted of interviews with farmers, fishermen and seaweed growers. A total of 296 individuals were interviewed in the survey. Out of these, 98 were fishermen, of whom 50 were from Kiuyu Mbuyuni and 48 from Matemwe, 98 were farmers with 49 from each ward, and 100 were seaweed growers, representing 50 from each study site. In the survey, three major areas were explored to demonstrate the nature of coping and adaptation responses to perceived climate variability and change and other linked stressors across the sites. These areas included: i) the identification of coping and adaptation responses for each livelihood sector (farming, fishing and seaweed growing), ii) the barriers blocking adaptation responses within respective sectors and at the household level, and iii) the reasons for discontinuing responses. All questions were unpromoted and open-ended to avoid influencing or biasing the responses given. However, this also runs the risk of underreporting, particularly where, for example, people may be employing multiple coping or adaptation responses, and some might not be mentioned during the interview. With regard to adaptation, farmers, fishermen and seaweed growers were asked to identify the actions and strategies they used in response to a wide range of climate and non-climate stressors (see Makame 2013; Makame and Shackleton 2019 for examples of these stressors) We then considered these responses in terms of the categories of adaptation strategies outlined in the introduction above. In terms of barriers to adaptation, respondents were asked two questions: firstly, whether there were adaptive options at both the sector and household level that they would wish to adopt; and secondly, they were asked to identify barriers that constrained them from adopting these responses. With regard to discontinuing some responses, the farmers, fishermen and seaweed growers were asked two questions: firstly, whether they had discontinued any previously adopted coping or adaptation responses; and secondly, respondents who answered 'yes' were asked to identify the options that they had discontinued and the reasons for this. For all questions the interview responses were tallied and presented as percentages across each of the livelihood sectors and sites. Additionally, data from individual semi-structured interviews and participatory learning and actions (PLA) activities were also used to provide more in-depth information related to responses and barriers.

\section{Results And Discussion}

\subsection{Coping and adaptation in the small-scale farming sector}

Bearing in mind the size of the sample, which entails a total of 296 individuals, we use descriptive statistics, since this method caters for an accurately reporting of the findings. 
For decades, farmers along the east coasts of Zanzibar have coped with and adapted to the double difficulties of variable rainfall and poor soil quality (Makame, 2013). As a result, the most-cited responses designed to cope with these two variables were autonomous, anticipatory or strategic (Table 1). The data from the survey show that $18 \%$ of farmers in Kiuyu Mbuyuni and $22 \%$ in Matemwe used fast-maturing varieties of maize, cowpeas, and millet to cope with dry spells and variability in the onset of the rainfall seasons. It was noted during the survey that farmers used maize seeds and cowpeas that could be harvested after 90 days and 60 days, respectively. To cope with poor soils in the areas, farmers used methods such as crop rotation, mixed farming, intercropping, and shifting cultivation. Mixed farming in this context involves a combination of livestock and crops and is a common strategy along the east coasts of both islands to cope with unfertile coral rag soils. In the past, shifting cultivation was common along the east coasts of both islands, due to low populations. However, as the population grew, villages expanded and the demand for land increased, thus the feasibility and popularity of shifting cultivation has declined.

Other responses to cope with dry spells, cited only in Matemwe, included the use of irrigation using water from standpipes and dumping food-related waste on the homestead garden plots to increase soil fertility. Only a few farmers said that they 'do nothing'. The use of irrigation in Matemwe is probably because farm plots are located close to the homestead and thus farmers have access to piped water, contrary to the situation in Kiuyu Mbuyuni. However, the authority responsible for water supply in both islands has banned the use of water from standpipes to irrigate home gardens. The 'do nothing' responses may be influenced by a lack of knowledge regarding how to respond (Gifford, 2011), a lack of assets, or because the farmers do not believe that the climate is different. 
Table 1

Coping and adaptation responses identified by farmers

\begin{tabular}{|c|c|c|c|}
\hline Responses & $\begin{array}{l}\text { Kiuyu } \\
\text { Mbuyuni, } \\
\text { Pemba }(n=47) \\
(\%)\end{array}$ & $\begin{array}{l}\text { Matemwe, } \\
\text { Unguja } \\
(n=47)(\%)\end{array}$ & Classification of responses \\
\hline Fast-maturing crops & 18 & 22 & Anticipatory/strategic adaptation \\
\hline Intercropping & 30 & 22 & Anticipatory/strategic adaptation \\
\hline Mixed farming & 38 & 28 & Anticipatory/strategic adaptation \\
\hline Irrigation & - & 3 & $\begin{array}{l}\text { Anticipatory/strategic adaptation (could } \\
\text { become maladaptive if it affects future water } \\
\text { supplies) }\end{array}$ \\
\hline Shifting cultivation & 10 & 15 & Tactical/coping \\
\hline Crop rotation & 6 & 6 & Anticipatory/strategic adaptation \\
\hline Do nothing & - & 6 & No response \\
\hline $\begin{array}{l}\text { Dumping food waste } \\
\text { on the homestead } \\
\text { garden plot }\end{array}$ & - & 1 & Anticipatory/strategic adaptation \\
\hline
\end{tabular}

Responses not cited in Table 1, but observed and cited during group discussions and interviews, included the use of baobab leaves as fodder, collecting grass outside the area, migrating with animals to look for pasture, and planting trees with leaves suitable for fodder. These are strategies used to respond to the declining rainfall that adversely affects the local pasture. This is also demonstrated in the following comments made by livestock keepers in Kiuyu Mbuyuni, Pemba.

I have never sold or lost my cattle due to dry spells which adversely affect grazing land in our area. My cattle survived various dry spells before, because I used to go out of this area by bicycle to the areas which experience rainfall regularly to collect fodder for my cattle'.

'During drought, livestock suffered a lot due to lack of grass. Some of the livestock keepers go to other places to collect grass for their cattle. Some people perform a short-term migration with their cattle to the west or central corridor where rainfall is readily available until the situation becomes better. To migrate is not the only solution for me. I have planted indigenous trees (locally known as mkone) with edible leaves for cattle'.

Baobab trees are a common tree species across the sites and are minimally affected by declining rainfall or drought. Across the sites, the majority of the baobab trees had their branches lopped, which demonstrates the use of their leaves as fodder during dry spells. Another tactical strategy used by livestock keepers, in response to the increasing salinity content in the caves and wells during dry spells, was to use tap water where available. The findings coincide with findings in many parts of Africa. For example, in the Niger Delta, farmers were found to delay their planting time and grow fast-maturing varieties of maize and cassava to cope with declining rainfall and seasonality (Uyigue and Agho, 2007). In the Sahel part of Nigeria, farmers increased 
livestock-crops (mixed farming) integration, increased farming inputs (including labour), and diversified their livelihoods as responses to increasing variability in climate (Mortimore and Adams, 2001). In Kenya, smallscale farmers changed crop varieties and planting dates, planted trees, decreased the number of livestock, implemented soil water management, and changed fertilizer application in order to cope with and adapt to climate variability and other stressors (Bryan et al. 2010).

\subsection{Coping and adaptation in the small-scale fisheries sector}

The findings reveal that just over one third of fishermen across the study sites were 'doing nothing' to respond to the perceived decline of fish catches triggered by climate variability and change and overfishing (Table 2). Apart from doing nothing responses, Table 2 presents various autonomous coping and adaptation responses mentioned by fishermen. About 32\% of fishermen in Kiuyu Mbuyuni and $17 \%$ in Matemwe used a variety of fishing methods during a single fishing trip or shifted from one method to another, based on the season, to maximise their catch. Another more tactical response amongst fishermen in both sites (14\% in Kiuyu Mbuyuni and $2 \%$ in Matemwe) was to regularly change fishing grounds. The regular change of fishing grounds carried out by small numbers of fishermen is attributed to the limitations imposed by the marine conservation area nearby, which is perceived to be seriously reducing access to key fishing grounds (Makame, 2013).

Furthermore, $6 \%$ of fishermen in Kiuyu Mbuyuni and $2 \%$ in Matemwe shifted from either shore fishing or small vessels (outrigger and dugout canoes) to motorised boats to increase the ability to reach distant, offshore sites. Such a move demonstrates that the fishing grounds inshore have already deteriorated, and the majority of shore fishermen would like to obtain vessels that will take them offshore. However, there are barriers to this strategic response as discussed in the next section. Similarly, about $4 \%$ of the fishermen in Kiuyu Mbuyuni and $2 \%$ in Matemwe collectively pooled their resources and built their own vessels. This is also highlighted by a fisherman in Kiyu Mbuyuni, Pemba:

"Building a fishing boat is not easy as it is very expensive, my children who work in town saved some money and together with my efforts I managed to own this boat. I can now see the difference - because of this ownership my income out of fishing also increased".

This demonstrates the power of social capital in influencing access to other capitals. It is evident that increasing the ownership of fishing assets such as vessels is likely to increase disposable income and adaptation amongst fishermen. In Bangladesh, fishermen are trying to adapt by buying technologically better boats to cope with storms in the ocean (Islam et al. 2014)

To deal with over-exploitation of some species and target species that are in demand and command a high price at the market, $4 \%$ of the respondents in Kiuyu Mbuyuni and $2 \%$ in Matemwe turned to octopus fishing to maximise their income. Octopuses are a highly marketable seafood in Zanzibar and other tourist destinations along the coast, such as Mombasa. In Brazil, fishermen were also targeting unexploited species, such as crustaceans (crabs), and abundant species in high demand, such as menhaden (Brevoortia spp.), to adjust to variability in the marine environment triggered by a changing climate (Kalikoski et al. 2010). A response cited only in Kiuyu Mbuyuni was to change the fishing time from day to night. This move was meant to target small pelagic species such as anchovies and mackerel that are normally caught at night and, in most cases, in large schools. Responses unique to Matemwe included increasing the number of hooks per line (6\%), using GPS to navigate and locate fish stocks (6\%), and refrigerating the catch, mentioned by $2 \%$ of fishermen. The use of 
GPS demonstrates the unpredictability of fish stock distribution in the territorial water. Normally, fishermen use signs on the shore like telephone towers and tall trees as well as stars to navigate and locate fish stocks at sea, but as some of them have increased the distance offshore, these signs can no longer be seen, and thus the use of GPS equipment is an important strategic response.

Although no one mentioned aquaculture (crab farming) in Kiuyu Mbuyuni, it was observed during fieldwork that some people are engaged in crab farming, in addition to other activities, to increase their income and improve their livelihood security. Kiuyu Mbuyuni, with its massive mangrove ecosystem, is an ideal spot for the future development of aquaculture. The increased participation of local communities in crab farming may have a significant impact on their livelihoods, as crab and other aquaculture products such as shrimp are in high demand in urban and tourist markets. A study by Sheriff et al. (2008) in southern Thailand shows that aquaculture is not only a potential alternative source of income for coastal communities and fishermen, but also a means of reducing pressure on scarce marine resources. Similarly, across the sites, no one mentioned temporary migration (locally know as dago) as a response to adjust to seasonality. In fact, dago is practised among fishermen; however, its intensity has declined over time as the majority of the small islets surrounding the main islands that were used as fishing camps have been leased out to tourism investors. Elsewhere, both long and short-term migrations are common responses for coping with seasonality and extreme events such as ENSO (Njock and Westlund, 2010; Nagy et al. 2009). 
Table 2

Coping and adaptation responses identified by fishermen

\begin{tabular}{|c|c|c|c|}
\hline Responses & $\begin{array}{l}\text { Kiuyu } \\
(\mathrm{N}=50) \\
(\%)\end{array}$ & $\begin{array}{l}\text { Matemwe } \\
(\mathrm{N}=46)(\%)\end{array}$ & Classification of responses \\
\hline Do nothing & 34 & 37 & No response \\
\hline $\begin{array}{l}\text { Increase the number of hooks } \\
\text { per line }\end{array}$ & - & 6 & Tactical/coping \\
\hline Use GPS & - & 6 & Anticipatory/strategic adaptation \\
\hline Use a variety of methods & 32 & 17 & Anticipatory/strategic adaptation \\
\hline Change fishing grounds & 14 & 2 & Tactical/coping \\
\hline $\begin{array}{l}\text { Change from traditional vessels } \\
\text { to motorised boat }\end{array}$ & 6 & 2 & Anticipatory/strategic adaptation \\
\hline Engaged with octopus catching & 4 & 2 & $\begin{array}{l}\text { Tactical/coping (could become } \\
\text { maladaptive if overfished) }\end{array}$ \\
\hline Use refrigeration & - & 2 & Anticipatory/strategic adaptation \\
\hline $\begin{array}{l}\text { Build own dhow with fellow } \\
\text { fishermen }\end{array}$ & 4 & 2 & Anticipatory/strategic adaptation \\
\hline $\begin{array}{l}\text { Increase depth for walking } \\
\text { fishermen }\end{array}$ & 4 & 2 & Tactical/coping \\
\hline $\begin{array}{l}\text { Change fishing time (from day to } \\
\text { night) }\end{array}$ & 2 & - & Anticipatory/strategic adaptation \\
\hline Source: Filed data (2013) & & & \\
\hline
\end{tabular}

Similar findings to those presented here have been observed for other fishing communities. For example, a study by Nagy et al. (2009) showed that fishermen in the Rio de la Plata, South America used a wide range of coping strategies ranging from reactive to planned private strategies, such as long-term migration to cope with declining fish catches attributed to ENSO events. In Patos Lagoon, Brazil, livelihood diversification amongst fishermen during bad seasons is a major adaptation response by small-scale fishermen (Kalikoski et al. 2010). According to Kalikoski et al. (2010), fishermen who managed to diversify their portfolio during unfavourable seasons or exit fishing for off-fishing activities were better off than those fishermen who did nothing.

\subsection{Coping and adaptation in the seaweed-growing sector}

The most common responses adopted by seaweed growers to cope with variability and changes in climate and other related stressors were autonomous and a mix of tactical and strategic responses (Table 3). However, as discussed later, even responses that can be considered strategic face constraints due to competition for space. Responses identified included shifting to deeper water, increasing the number of cultivated seaweed blocks, and shifting cultivation from one place to another (Table 3). Some $27 \%$ of the respondents in Kiuyu Mbuyuni and 13\% in Matemwe shifted their seaweed plots to cope with the perceived increased of temperature in the shallow water and the increased incidence of diseases that affect seaweed. 
According to Coates (2018), the added warmth in Zanzibar shallow water where seaweed grows creates conditions ideal for plant diseases like ice-ice, which stresses the algae and makes them susceptible to bacteria. In Kiuyu Mbuyuni, Pemba, for example, some seaweed growers believed that moving their plots to deeper water to avoid exposure had increased the yield per block and their income. About $23 \%$ of the seaweed growers interviewed in Kiuyu Mbuyuni and 11\% in Matemwe indicated that they had shifted their seaweed blocks from one place to another to cope with the perceived decline in fertility. More seaweed growers in Kiuyu Mbuyuni opted to shift their seaweed plots because they still have space to do so. This is contrary to the situation in Matemwe, where tourism activities in the intertidal zones and the insensitivity of the hoteliers push seaweed growers into small areas that do not permit such movement.

With regards to increasing the number of seaweed plots, $22 \%$ of the seaweed growers in Kiuyu Mbuyuni and $5 \%$ in Matemwe had added new seaweed plots to their area over the seasons to cope with both natural variability and the low price paid by seaweed buyers. The difference in responses between the two sites may again be influenced by the limited intertidal space available for seaweed farming in Matemwe as explained above. One reactive, short-term coping strategy identified was the replanting of seaweed after the damage caused either by wind and wave intensity or temperature variability.

Furthermore, $10 \%$ and $52 \%$ of seaweed growers in Kiuyu Mbuyuni and Matemwe, respectively, reported doing nothing in response to the perceived decline in sea water level (which was due to more sand deposition with higher storm surges and rising sea level), the low price of seaweed, and the increasing intensity of winds and temperature. The observed difference in response to the 'do nothing' category between sites is probably influenced by the fact that seaweed growers in Matemwe are deeply discouraged by the pressure on space. Tourism expansion in terms of infrastructure has robbed growers of the areas previously used for drying seaweed, while increasing tourism activities within the intertidal areas confine growers to smaller areas. Not knowing what to do may be another factor influencing a 'do nothing' response. In examining how coastal communities in the Philippines adapted to the impact of climate change, Campos (2010) identified various strategies used by seaweed growers in response to both climate and non-climate factors. These include removing algae, epiphytes and mud that can cause seaweed diseases and shifting seaweed plots from crowded to less crowded zones where water moves freely. Other options include 'harvesting plants as soon as diseases occur' and lowering the ropes further down 'from the water surface to prevent too much exposure to sunlight, especially during low tides' (Campos, 2010). 
Table 3

Coping and adaptation responses identified by seaweed growers

\begin{tabular}{|c|c|c|c|}
\hline Adaptation & $\begin{array}{l}\text { Kiuyu Mbuyuni, } \\
\text { Pemba }(\mathrm{N}=49)(\%)\end{array}$ & $\begin{array}{l}\text { Matemwe, } \\
\text { Unguja }(\mathrm{N}=50) \\
(\%)\end{array}$ & Classification of responses \\
\hline Shift to deep water & 27 & 13 & Anticipatory/strategic adaptation \\
\hline Add more blocks & 22 & 5 & $\begin{array}{l}\text { Anticipatory/strategic adaptation } \\
\text { (lack of space is a barrier) }\end{array}$ \\
\hline Do nothing & 10 & 52 & No response \\
\hline Shift cultivation & 23 & 11 & $\begin{array}{l}\text { Tactical/coping (lack of space is a } \\
\text { barrier) }\end{array}$ \\
\hline Replace after damage & 11 & 19 & Tactical/coping \\
\hline $\begin{array}{l}\text { Find new seaweed } \\
\text { branches for planting }\end{array}$ & 7 & - & Tactical/coping \\
\hline
\end{tabular}

\subsection{Discontinuance of adaptation strategies}

In this study, 'discontinuance' is defined as the breaking off (temporarily or permanently) of certain coping and adaptation responses. Discontinuance may be influenced by the declining capability of the actor to maintain the response or the failure of the response to meet the desired outcome. Since local people across the sites have coped and adapted previously to erratic rainfall, variations in winds, fishing seasonality, and poor soil, the respondents were asked if they had discontinued any responses that helped them to cope in the past. The results show that more than $50 \%$ of the respondents across the sites and categories indicated that they had not discontinued any of their responses to the shocks and stressors experienced. Since most farmers, fishermen and seaweed growers primarily adapt within their sectors, they continued to pursue their chosen options to cope with multiple stressors, as these activities form the backbone of their livelihoods. Those who answered 'yes' were asked to identify the responses they had discontinued and the reasons for this (Table 4).

The most prominent coping and adaptation responses discontinued across the sites included small businesses, livestock and poultry keeping, and participation in cooperative and saving groups (Table 4). Respondents mentioned that a lack of adequate capital and unrecovered credit were the reasons that people battled to continue their businesses. Unrecovered loans/credit, especially food loans, were said to be particularly responsible for the demise of established food stores in the neighbourhood. Poverty and low returns from natural resource-based activities were some of the reasons for poor recovery of these loans. The findings across livelihood categories show that more people have discontinued small businesses in Kiuyu Mbuyuni, Pemba, the poorer island, than in Matemwe, Unguja.

Regarding livestock and poultry keeping, the results demonstrate that amongst fishermen, $19 \%$ in Kiuyu Mbuyuni and 13\% in Matemwe had discontinued taking part in livestock and poultry keeping. Similarly, 32\% and $48 \%$ of farmers in Kiuyu Mbuyuni, Pemba and Matemwe, Unguja, respectively, did the same. The reasons for discontinuation included drought, diseases that affect livestock and poultry, theft, and failure to recover 
from the previous loss of livestock and poultry. Discontinuation of livestock and poultry keeping may have serious implications for the well-being of households, because livestock and poultry act as a live bank, a reserve for contingencies, and a source of manure to cope with the poor quality of soils. That said, some farmers indicated mixed farming as a response to shocks and stressors (Table 1). Different conditions, situations, and preferences mean that some famers continue with mixed farming, while others drop the livestock component. Those who had discontinued livestock farming reported the increasing frequency of dry spells and declining rainfall, which adversely affects grazing land in terms of grass quality and quantity. The variability in climate also affects water availability and influences the occurrence of climate-related pests and livestock diseases. A combination of these factors, as well as the incapacity to recover from past shocks due to poverty, is responsible for discontinuance. This response regarding the removal of livestock from the livelihood portfolio is somewhat unusual - more often farmers in mixed farming areas will reduce efforts in cropping and focus on livestock production (e.g. Thornton et al. 2015; Descheemaeker et al. 2016; Moll, 2005). The difference in the Zanzibar context may be due to the limited space for alternative pastures.

In terms of discontinued participation in cooperative groups and saving groups, the results show that $16 \%$ of the seaweed growers interviewed in Kiuyu Mbuyuni and 19\% in Matemwe stopped participating in the local women's cooperative group. Similarly, $10 \%$ of the fishermen interviewed in Matemwe also suspended their participation in the fishing cooperative group; the reasons cited for discontinuing were mainly related to financial issues, their capacity to contribute, and trust among members. While the proportion of people discontinuing with these activities is relatively small, it is still concerning, as such cooperative social innovations are considered important for supporting coping and adaptation (Eriksen and O'Brien, 2011; Kihila, 2018). If people are leaving such groups (likely the most vulnerable), then more understanding is needed as to why and how the groups can be made more beneficial for all members.

These results suggest that some people are divesting in livelihood activities that could contribute to diversification of the livelihood portfolio. Diversification is often promoted as a strategy to decrease risk and vulnerability to multiple shocks and stressors (Brycesson, 2014; Ellis, 1998; Kihila, 2018; Berman et al. 2015). This raises the question of whether discontinuation of certain livelihood activities could be considered a form of maladaptation. 
Discontinued coping and adaptation responses

\section{Fishermen}

$\begin{array}{llll}\text { Discontinued strategies } & \begin{array}{l}\text { Kiuyu } \\ \text { Mbuyuni } \\ (\mathrm{N}=22)(\%)\end{array} & \begin{array}{l}\text { Matemwe } \\ (\mathrm{N}=16)\end{array} & \text { Reasons for discontinuance } \\ & & \end{array}$

Middlemen

14

Small business

Small-eye nets and

beach seine and spear

guns

Livestock and poultry

keeping

Cooperative fishing

group

\section{Seaweed growers}

\section{Discontinued strategies}

\section{Kiuyu}

Mbuyuni

$(\mathrm{N}=17)(\%)$

23

26

Poultry

Small business

Seaweed shifting

cultivation

Tourism related

Women's cooperative

groups

\section{Farmers}

\section{Discontinued strategies}

Kiuyu

Mbuyuni

$(\mathrm{N}=13)(\%)$

16

\section{5}

- $\quad 31$

Conflicts within the group, mistrust
Matemwe

$(\mathrm{N}=16)$

(\%)

13

19

Market

Diseases, theft

Drought, failure to reco
cattle, theft, disease

Loss, not enough capital

Loss, capital, loans

Banned methods of fishing

Reasons for discontinuance

Loss, market

13 Loss, market

19 Tourism

$31 \quad$ Marriage

19 Conflicts on financial issues

\begin{tabular}{llll} 
Dairy cattle & - & 6 & Drought, diseases \\
Small businesses & 30 & 11 & Loss, market \\
\hline Seaweed farming & 23 & 10 & $\begin{array}{l}\text { Low income in relation to the nature of work, } \\
\text { social status }\end{array}$ \\
\hline Shifting cultivation & 15 & 17 & Scarcity of land
\end{tabular}

Source: Filed data (2013) 


\section{Fishermen}

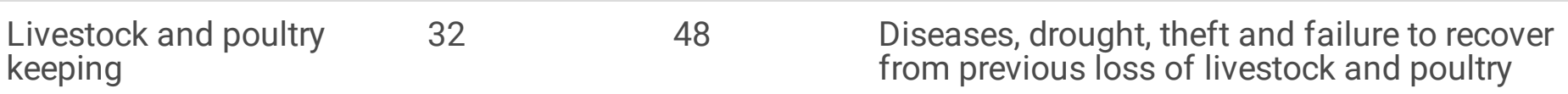

Small restaurant

6

Low profit

Source: Filed data (2013)

\subsection{Alternative response options and their barriers within and outside of fishing, seaweed growing and farming}

Regarding possible alternative responses to climate and non-climate shocks and stressors, it was found that, across all three livelihood sectors, a significant number of respondents mentioned that they would like to diversify from their traditional activities that are sensitive to climate change and engage in small businesses (middlemen, small food store etc.), but they were constrained by barriers such as lack of initial capital (Table 4). This could be linked to a low access to cash due to low savings, low participation in cooperative and saving groups (Makame, 2013), and a lack of credit facilities (Mohamed 2003). However, despite this desire to move into small businesses, we saw, above, that the small business option can be challenging, and that some respondents were forced to discontinue this as a strategy. Low access to credit amongst fishing and farming communities is commonly observed in the developing world (Islam et al. 2014; Allison and Ellis, 2001; Yadav et al. 2015; Linh et al. 2019; Twumasi et al. 2020). A study by Twumasi et al. (2020) in Ghana found that limited access to credit is a constraint for the artisanal fishermen for increasing investment and thus adapting to various risks.

Across the sectors and sites, respondents mentioned that irrigation for both crops and vegetables would help them to cope with the decline in rainfall and the unreliability of the seasons. However, they are constrained by barriers such as the lack of assistance, poor rural electrification, lack of knowledge related to rainwater harvesting, and pests and diseases. Local people believe that some of the coral caves contain water with a low salinity content that could be used for irrigation. In areas with unreliable rainfall and poor soils, support in the form of rainwater harvesting, access to irrigation facilities (drip system of irrigation), and agricultural inputs would help to increase farming resilience. Discussion during the focus groups revealed that the survival of female farming groups, especially those related to vegetable growing, are threatened by unreliable rainfall coupled with the lack of access to technologies or mechanisms that will help farmers to tap other sources of water. This is also highlighted by the farmers in Matemwe, Unguja:

"In our group we cultivate vegetables such as green peppers and tomatoes, but the production is not good most of the time as we don't have infrastructure for water irrigation. We asked for support for drip irrigation, but we did not succeed; we don't have money to invest in this technology"

Another possible adaptive option cited in both sites, but only amongst farmers and fishermen, is to engage in seaweed farming to diversify their livelihood portfolio in order to increase their resilience. About $13 \%$ of the farmers in Kiuyu Mbuyuni and 19\% in Matemwe, and similarly 5\% of fishermen in Kiuyu Mbuyuni and 16\% in Matemwe, would like to adopt this activity. However, old age (individual factor) and social status were cited as barriers to this. It is important to note that all of the respondents who would like to start seaweed growing 
were males. Since its inception in the early 1990s, seaweed growing in Zanzibar has been perceived as a woman's occupation. Despite the increasing popularity of seaweed growing among males, mainly due to the unreliability of other livelihood activities (farming and fishing), some respondents were still unwilling to cross this social norm. Findings mirror results of other studies within Africa. For example, a study by Nielsen and Reenberg (2010) found that the local people's perceptions of emerging job opportunities, such as migrant labour, acted as a barrier towards them embarking on these new jobs. Furthermore, the findings in Table 5 indicated that $11 \%$ and $13 \%$ of fishermen and seaweed growers, respectively, would like to adopt aquaculture (crabs farming) but they were constrained by the lack of skills and knowledge on how to do it.

Data from surveys also show that illiteracy, the local people's perceptions of tourism, and the perceptions of investors regarding the ability of local people to work in the tourism sector inhibit local people from being employed in tourism related jobs, while initial capital and skills in managing modern poultry and dairy cattle prevent them from adopting these options. Women are often barred from participating in tourism-related work for social and religious reasons. In many rural areas in Zanzibar, tourism-related work is perceived to be immoral, especially for women. Generally, tourism-related jobs in Zanzibar remain out of reach for the majority. An interview with an informant from an NGO revealed that, in addition to the villager's low level of education, hotel owners have a bad perception of their capabilities. The informant reported that only two hotels out of 14 in Matemwe, Unguja employ about 10 villagers. Recently, 70 local villagers were trained and graduated through a local empowerment scheme run by an NGO, but none had been employed so far.

Furthermore, significant percentages of fishermen across the sites ( $46 \%$ in Kiuyu Mbuyuni and $64 \%$ in Matemwe) wished to own motorised boats for fishing (Table 5). However, barriers such as initial capital, savings, poverty, and lack of support were found to inhibit fishermen from purchasing motorised boats and modern gear. Given the low degree of support towards the provision of modern gear and vessels, improved access to financial assets would be the only option that could help fishermen. The observed low access to modern vessels and gear may push fishermen into the use of illegal methods that could further weaken ecological resilience, as this comment by a fisherman in Matemwe shows: 'We are forced to use them [illegal fishing methods] because we had no means of getting legal gear'. In Pato Lagoon, Brazil, small-scale fishermen were assisted by the government in various ways in order to cope with declining fish stock and improving resilience of the reef (Kalikoski et al. 2010).

With regards to the barriers that are specific to seaweed growing, $13 \%$ of the respondents in Kiuyu Mbuyuni and $3 \%$ in Matemwe would like to shift their seaweed plots seaward to avoid exposure to the sun, but are constrained by their age. They are too old to be able to work in that environment, as it needs extra strength. Massive deposition of sand has resulted in the majority of the seaweed growers perceiving a decline in sea water level in the intertidal zones where seaweed farms. To cope with this decline, the affected seaweed farmers shifted from areas with shallow seawater to deeper water. For better growth, seaweed should remain under water even during the low tides to avoid exposure to the direct sunlight. 
Table 5

Potential adaptation options that farmers, fishermen and seaweed farmers would like to adopt inside and outside their sectors, and barriers to these

\section{Farmers}

$\begin{array}{lll}\text { Adaptations } & \begin{array}{l}\text { Kiuyu } \\ \text { Mbuyuni } \\ \mathrm{N}=22(\%)\end{array} & \begin{array}{l}\text { Matemwe } \\ \mathrm{N}=16(\%)\end{array} \\ & & \end{array}$

Irrigation for crop and 14

vegetable farming

20

Lack of assistance, poor rural electrification and knowledge related to rainwater harvesting, pest and diseases

$\begin{array}{lccl}\text { Start small business } & 73 & 27 & \text { Initial capital, low saving } \\ \begin{array}{l}\text { Start seaweed } \\ \text { farming }\end{array} & 13 & 19 & \text { Old age, social status } \\ \begin{array}{l}\text { Use of } \\ \text { fertilizers/insecticides }\end{array} & - & 20 & \text { Poverty } \\ \begin{array}{l}\text { Keeping livestock and } \\ \text { poultry }\end{array} & - & 8 & \text { Initial capital, poverty } \\ \text { Looking for } & - & 8 & \text { No opportunities, education }\end{array}$

employment

Fishermen

$\mathrm{N}=20 \quad \mathrm{~N}=16$

Start seaweed

farming

$5 \quad 16 \quad$ Social and cultural

Owning motorised

boat with modern

$46 \quad 64$

Initial capital, poverty, low savings, lack of support

nets

Irrigation for crop and

vegetable farming

Starting small

business

Tourism-related

activities

Aquaculture (crab

farming)

Joining savings

groups/clubs

Farming outside

village /deep soil

Seaweed farmers
39

9 Unreliable rainfall, lack of assistance, poor rural electrification and knowledge related to rainwater harvesting, pest and diseases

Savings, capital

Access to education, perception of the investors on local community

Skills and knowledge on how to do it

Low return from fishing

Distance, transport 


\section{Farmers}

\begin{tabular}{|c|c|c|c|}
\hline Start small business & 36 & 50 & Initial capital, business skills and market \\
\hline $\begin{array}{l}\text { Start irrigation for } \\
\text { crops vegetable } \\
\text { farming }\end{array}$ & 10 & 18 & $\begin{array}{l}\text { Lack of assistance, poor rural electrification and } \\
\text { knowledge related to rainwater harvesting, pest and } \\
\text { diseases }\end{array}$ \\
\hline $\begin{array}{l}\text { Move to deeper water } \\
\text { to reduce exposure }\end{array}$ & 13 & 3 & Old age, lack of swimming survival skills \\
\hline $\begin{array}{l}\text { Aquaculture (crab } \\
\text { farming) }\end{array}$ & 13 & - & Skills and knowledge on how to do it \\
\hline Keeping goats & 30 & - & Perceptions, superstitions \\
\hline $\begin{array}{l}\text { Keeping poultry and } \\
\text { dairy cattle }\end{array}$ & - & 18 & Skills and gender roles \\
\hline $\begin{array}{l}\text { Tourism-related } \\
\text { activities }\end{array}$ & - & 12 & Social, cultural, gender roles \\
\hline
\end{tabular}

\subsection{Adaptation framework}

Based on the findings, we have developed an integrated framework (Fig. 2) to help explain adaptation amongst farmers, seaweed growers, fishermen, and households to climate variability and other linked stressors in Zanzibar's east coastal areas. We illustrate how coastal and marine resources and their associated livelihoods (B) are exposed to climate variability and change, and other linked stressors (A). The decision of a decision unit (C) (e.g. crop and livestock farmers, seaweed growers, fishermen or households) to cope with and adapt to the risks related to climate change and other linked stressors is influenced by a wide range of barriers, such as financial constraints and access to materials and technologies. Individuals or households need to overcome these barriers, designated as D1 and D2. D1 comprises barriers such as social, cognitive and human informational, whereas D2 involves capital stocks or livelihood assets and access to these. The latter relates to the extent an individual or household is able to access and utilise various capitals (natural, social, financial, human and physical).

The successful coping and adaptation to multiple climate and non-climate stressors is influenced by the degree to which a decision unit manages to overcome the barriers, with the outcome of this designated by E1, E2, E3, E4 and E5. E1 represents successful long-term, strategic adaptation, meaning an adaptation process or action whose positive impacts are observed over several years. Most of the carefully planned strategic adaptations fall under this category. For example, with regard to fishing, the response of increasing physical capital through the ownership of vessels can be considered as a long-term, strategic adaptation. Other strategic adaptations observed included the use of GPS, targeting high value species, shifting seaweed blocks to deeper sea water, the use of fast maturing crops, and the planting of trees with leaves edible for livestock.

E2 represents short-term, tactical adaptation or coping. For example, harvesting seaweed once affected by diseases or collecting pasture from different localities to cope with unexpected dry condition falls under this category. E3 represents local responses that should be long term but are discontinued after being affected by 
barriers or other factors, such as the loss of assets that forces the adopters to discontinue the adopted options. These included small businesses, savings and cooperative groups, and shifting cultivation, among others. E4 represents maladaptation, i.e., a modality of adaptation where the benefits are very short-lived or may even be counter-productive or undermine the adaptation process or activity. Some adaptive responses, such as illegal methods of fishing to cope with declining fish stock or unavailability of proper fishing gear and quarrying on farmlands to cope with poor yield can be considered maladaptive, as they may compromise the sustainability of resources on which future adaptations are based.

Outcome E5 represents a 'do nothing' approach. Failure to overcome barriers (D1 and D2) is likely to generate a 'do nothing' response in a segment of the population. This outcome is attributed to the lack of means to adapt or a poor understanding of the dynamic nature of the risks faced from both climate and non-climate stressors. Since adaptation involves various sub-processes, Moser and Ekstrom (2010) argued that successful adaptation needs systematic identification of barriers to adaptation in each process. According to these authors, "the refined ability to identify where the most challenging barriers might lie affords the opportunity to better allocate resources and strategically design processes to overcome them" (Moser and Ekstrom, 2010:22031).

There are some incongruities in the responses provided. For instance, whereas mixed farming is a popular response to climate and non-climatic stressors, some respondents stated they had discontinued livestock and poultry farming. There were multiple reasons provided for this, such as not rebuilding their herds after their loss due to drought, concerns about diseases that increase the cost of production and often reduce the quality of meat, and lack of grazing, amongst others.

Overall, the variety of measures in the adaptation framework here described demonstrate one important factor: it is essential not only to initiate but also to provide on-going support for appropriate responses to multiple stressors to prevent or minimise the discontinuance of such activities and a narrowing of the livelihood portfolio and the resulting inability to adapt in the long-term.

\section{Conclusion}

Since humanity has coped and adapted before to various risks, the findings are similar to findings elsewhere, although some of the observed responses are unique to these areas. While many people across the sites and sectors had taken some autonomous action in response to changes in local climate and other stressors, between one third of fishermen and up to $50 \%$ of seaweed growers reported doing nothing. Interestingly, this was not the case for farmers. There could be many reasons behind this that are related to a lack of assets or numerous barriers, including knowledge of options and cognitive barriers such as attributing the changes to God's will. This suggests that there needs to be more planned adaptation, such that more people can respond

to the changes already observed; the results clearly suggest that some groups and individuals are not going to manage on their own. Furthermore, we found that, despite the fact that some people had succeeded in adapting, they were still affected by difficulties and many were forced to discontinue the strategies they had adopted. Some of these barriers were operating beyond their control and again need external support to overcome. We argue, given that many communities are already acting on their own, that building resilient coastal communities in Zanzibar is possible. But apart from greater political will, it needs social support, 
financial resources, and knowledge exchange and education in order to build adaptive capacities and capabilities. The combined deployment of such actions may help to overcome the barriers to adaptation seen in Zanzibar and other island regions.

This study has a limitation in the sense that the total population of 296 individuals, does not cater for a full picture about climate change adaptation on the island of Zanzibar. Also, the study focused on two major islands of Zanzibar, namely Kiuyu Mbuyuni on Pemba Island and Matemwe on Unguja Island, and did not cover all its territory. Despite these limitations, this study provides a welcome addition to the literature on climate change adaptation on island environments, whose specific conditions require a particular approach in respect of the design of the measures needed to cope with changing climate conditions.

We believe that some of the lessons from this study can be extended in terms of understanding adaptation in other island environments. The study demonstrated the many elements that need to be considered if attempts to foster climate change adaptation are to yield the expected results. This study and the experiences from it may have useful implications for those living and working in rural areas on island regions, since it illustrates the various integrated response measures that are necessary in order to: i) enhance adaptive capacity, ii) prevent and/or mitigate potential or expected impacts, and ii) support actions in the medium and long term which may help to control the impacts of shocks and stressors, assist in reducing vulnerability, and support efforts towards strengthening resilience.

\section{Declarations}

\section{Ethical statement}

The methods were carried out in accordance with relevant guidelines and regulations in Germany. There was no need for an ethics approval since the work performed entailed exclusively anonymous data. There were no experiments, so no experimental protocols were needed. The informed consent was required and provided by all those who took part in the research responding to the survey.

\section{References}

1. Adger, W.N., 2003. Social capital, collective action, and adaptation to climate change. Economic Geography, 79, 387-404.

2. Adger, W.N., Dessai, S., Goulden, M., Hulme, M., Lorenzoni, I., Nelson, D.R., Naess, L.O., Wolf, J., and Wreford, A., 2009. Are there social limits to adaptation to climate change? Climatic Change, 93, 335-354.

3. Allison, E.H., and Ellis, F., 2001. The livelihoods approach and management of small-scale fisheries. Marine Policy, 25, 377-388

4. Barros, V., 2009. Adaptation to climate trends: Lessons from Argentine experience. In: Leary N., Adejuwon, J., Barros, V., Burton, I., Kulkarni, J., and Lasco, R., (Eds.), Climate change and adaptation. Earthscan, London, 296-314.

5. Belliveau, S., Smit B., and Bradshaw, B., 2006. Multiple exposure and dynamic vulnerability: Evidence from grape industry in the Okanagan Valley, Canada. Global Environmental Change, 16, 364-378. 
6. Below, T.B., Mutabazi, K.D., Kirschke, D., Franke, C., Sieber, S., Siebert, R., and Tscherning, K., 2012. Can farmers' adaptation to climate change be explained by socio-economic household-level variables? Global Environmental Change, 22, 223-235.

7. Berman, R.J., Quinn, C.H. \& Paavola, J., 2015. Identifying drivers of household coping strategies to multiple climatic hazards in Western Uganda: implications for adapting to future climate change, Climate and Development, 7, 71-84, DOI: 10.1080/17565529.2014.902355

8. Blennow, K., and Persson, J., 2009. Climate change: Motivation for taking measures to adapt. Global Environmental Change, 19, 100-104.

9. Bryan, E., Ringler, C., Okoba, B., Roncoli, G., Silvestri, S., and Herrero, M., 2010. Adapting to Agriculture to climate change in Kenya: Household and community strategies and determinants. Report to the World Bank. Available online at ftp://192.156.137.116/ifpri/ElizabethB/Kenya_project_outputs/Reports/KenyaWB_Report3a_FINAL.pdf [Accessed 20th May 2019]

10. Bryceson, D.F., 2004. African rural labour, income diversification \& livelihood approaches: a long-term development perspective. Review of African Political Economy, 26, 171-189, DOI: 10.1080/03056249908704377

11. Campos, M.R., 2010. Adaptation of coastal communities in the Philippines to the impacts climate change. Proceedings of the $22^{\text {nd }}$ International conference of the coastal society's, shifting shorelines: Adapting to the future. Wilmington, North Carolina. 13-16 June, 2010. Available online at http://aquaticcommons.org/3892/ [Accessed 6 ${ }^{\text {th }}$ April, 2019]

12. Coates, K.J., 2018. Warming waters hurt Zanzibar's seaweed, but women farmers have a plan. The Christian Science Monitor, Available online at https://www.csmonitor.com/World/Africa/2018/0521/Warming-waters-hurt-Zanzibar-s-seaweed.-Butwomen-farmers-have-a-plan [Accessed $12^{\text {th }}$ April, 2019]

13. Descheemaeker, K. Oosting, S.J., Tui, S.H., Masikati, P., Falconnier, G.N., Giller, K.E. 2016. Climate change adaptation and mitigation in smallholder crop-livestock systems in sub-Saharan Africa: a call for integrated impact assessments. Reg Environ Change, 16:2331-2343, DOI 10.1007/s10113-016-0957-8

14. Ellis, F., 1998. Household strategies and rural livelihood diversification, The Journal of Development Studies, 35:1, 1-38, DOI: 10.1080/00220389808422553

15. Eriksen, S.H., \& O'Brien K., 2007. Vulnerability, poverty and the need for sustainable adaptation measures, Climate Policy, 7, 337-352

16. Gifford, R., 2011. The dragons of inaction: Psychological barriers that limit climate change mitigation and adaptation. American Psychological Association, 66, 290-302.

17. Grothmann, T., and Patt, A., 2005. Adaptive capacity and human cognition: The process of individual adaptation to climate change. Global Environmental Change, 15, 199-213.

18. Huang, C., Vaneckova, P., Wang, X., Gerald, G.F., Guo, Y., and Tong, S., 2011. Constraints and barriers to public health adaptation to climate change: A review of the literature. American Journal of Preventive Medicine, 40, 183-190. 
19. Islam G.N., Shzee, T., Mustapha, N., Abdulla, R., and Viswanathan, K.K., 2011. Social capital, community based management and fisheries livelihood in Bangladesh. Ocean and Coastal Management, 54, 173180.

20. Islam, M.M., Sallu, S., Hubacek, K., Paavola, J., 2014. Limits and barriers to adaptation to climate variability and change in Bangladeshi coastal fishing communities. Marine Policy, 43, 208-216

21. Jones, L., 2010. Overcoming social barriers to adaptation. Background note. Overseas Development Institute. Available online at www.odi.org.uk. [Accessed $10^{\text {th }}$ January, 2018].

22. Jones, L., and Boyd, E., 2011. Exploring social barriers to adaptation: Insights from Nepal. Global Environmental Change, 21, 1262-1274.

23. Kalikoski, D.C., Quevedo, N.P., and Almudi, T., 2010. Building adaptive capacity to climate variability: The case of artisanal fisheries in the estuary of the Patos Lagoon, Brazil. Marine Policy, 34, 742-751.

24. Kihila, J.M., 2018. Indigenous coping and adaptation strategies to climate change of local communities in Tanzania: a review, Climate and Development, 10, 406-416, DOI: 10.1080/17565529.2017.1318739

25. Kuruppu, N., and Liverman, D., 2011. Mental preparation for climate adaptation: The role of cognition and culture in enhancing adaptive capacity of water management in Kiribati. Global Environmental Change, 21, 657-669.

26. Leal Filho, W., Oguge, N., Ayal, D., Adeleke, L. da Silva, I. (Eds) (2021) African Handbook of Climate Change Adaptation. Springer, Cham.

27. Linh, T.N, Long, H.T., Chi, L.V., Tam, L.T., Lebailly, P., Access to Rural Credit Markets in Developing Countries, the Case of Vietnam: A Literature Review. Sustainability, 11, 1468; doi:10.3390/su11051468

28. Makame, M.O., 2013. Vulnerability and adaptation of Zanzibar east coast communities to climate variability and change and other interacting stressors. PhD Thesis, Rhodes University, Grahamstown, South Africa.

29. Mohamed, Kh., 2003. Access to formal and quasi-formal credit by small holder farmers and artisanal fishermen: A case of Zanzibar, Research No. 03.6, REPOA, Mkuki na Nyota Publishers, Dar es Salaam, Tanzania.

30. Moll, H. 2005 Costs and benefits of livestock systems and the role of market and nonmarket relationships. Agric Econ 32:181-193. doi:10.1111/j.0169-5150.2005.00210.x

31. Mortimore, M.J. and Adams, W.M., 2001. Farmer adaptation, change and crisis in the Sahel. Global Environmental Change, 11, 49-57.

32. Moser, S.C., and Ekstrom, J.A., 2010. A framework to diagnose barriers to climate change adaptation. PNAS, 107, 22026-22031.

33. Muchuru, S. and Nhamo, G. (2017) Climate change and the African livestock sector: Emerging adaptation measures from UNFCCC national communications. International Journal of Climate Change Strategies and Management, 9 (2), pp. 241-260. https://doi.org/10.1108/IJCCSM-07-2016-0093

34. Mustelin, J., Klein, R.G., Assaid, B., Sitari, T., Khamis, M., Mzee, A., and Haji, T., 2010. Understanding current and future vulnerability in coastal settings: community perceptions and preferences for adaptation in Zanzibar, Tanzania. Population and Environment, 31, 371-398. 
35. Nagy, G.J., Bidegain, M., Caffera, R.M., Norbis, W., Ponce, A., Pshennikov, V., and Sererov, A.N., 2009. Fishing strategies for managing climate variability and change in the estuarine front of the Rio de la Plata. In: Leary N., Adejuwon, J., Barros, V., Burton, I., Kulkarni, J., and Lasco, R., (Eds.) Climate change and adaptation. Earthscan, London, 353-370.

36. Nielsen, J., and Reenberg, A., 2010. Cultural barriers to climate change adaptation: A case study from Northern Burkina Faso. Global Environmental Change, 20, 142-152.

37. Njock, J., and Westlund, L., 2010. Migration, resources management and global change: Experiencing from fishing community in west and central Africa. Marine Policy, 34, 752-760.

38. Orlove, B., 2005. Human adaptation to climate change: A review of three historical cases and some general perspectives. Environmental Science and Policy, 8, 589-600.

39. Osman-Ealsh, B., Goutbi, N., Spanger-Siegfried, E., Dougherty, B., Hanafi, A., Zakieldeen, S., Saryak, E., Ati, H.A., and Elhassam, H., 2007. Community development and coping with drought in rural Sudan. In: Leary N., Adejuwon, J., Barros, V., Burton, I., Kulkarni, J., and Lasco, R., (Eds.) Climate change and adaptation. Earthscan, London, 90-108.

40. Patt, A., and Gwata, C., 2002. Effective seasonal climate forecast applications: Examining constraints for subsistence farmers in Zimbabwe. Global Environmental Change, 12, 185-195.

41. Payet, R., and Obura, D., 2004. The negative impacts of human activities in the Eastern African region: An international waters perspective. Ambio, 33, 24-33.

42. Said, S., 2011. Ukame, mabadiliko ya tabianchi na umaskini Pemba. Mwananchi, $5^{\text {th }}$ May. Available online at http://www.mwananchi.co.tz/magazines/26-jungukuu/11650-ukame-mabadiliko-ya-tabianchina-umaskini-pemba.html [Accessed 10 th April 2019]

43. Shackleton, Ziervogel, G., Sallu, S., Gill, T. and Tschakert, P. 2015. Why is socially-just climate change adaptation in sub-Saharan Africa so challenging? A review of barriers identified from empirical cases? WIREs Climate Change 6: 321-344.

44. Sheriff, N., Little, D.C., and Tantikamton, K., 2008. Aquaculture and the poor-ls the culture of high-value fish a viable livelihood option for the poor? Marine Policy, 32, 1094-1102.

45. SMZ., 2016. Zanzibar Household Budget Survey 2014-2015. Zanzibar, Tanzania.

46. Spinage, C.A., 2012. African ecology-Benchmarks and historical perspectives. Springer Geography, Springer-Verlag Berlin Heidelberg.

47. Sultan, A., 2011. Zanzibar rising sea level erodes fertile arable lands. Daily news online edition, 28th Sept. Available on line at http://www.dailynews.co.tz/home/?n=24048\&cat=home, [Accessed 20 ${ }^{\text {th }}$ April, 2019].

48. Thornton, P.K. and Herrero, M. 2015. Adapting to climate change in the mixed crop and livestock farming systems in sub-Saharan Africa. Nature Climate Change, 5: 830-836, DOI: 10.1038/NCLIMATE2754

49. Thornton, T.F., and Manasfi, N., 2010. Adaptation-Genuine and spurious: Demystifying adaptation processes in relation to climate change. Environment and Society: Advances in Research, 1, 132-155.

50. TMA, 2019. Statement on the Status of Tanzania Climate in 2019. Tanzania Meteorological Authority, Tanzania. Available online at http://www.meteo.go.tz/uploads/publications/sw1586868749Climate_statement_2019.pdf 
51. Twumasi, M.A., Jiang, Y., Danquah, F.O., Chandio, A.A., Asiamah, B.K., 2020. Determinants of credit constraint of artisanal fishermen in Ghana. Ciência Rural, http://dx.doi.org/10.1590/0103-

8478 cr20190119

52. Uyigue, E., and Agho, M., 2007. Coping with climate change and environmental degradation in the Niger Delta of Southern Nigeria. Community Research and Development Centre (CREDC). Available online at www.credcentre.org/publications/adaptation-nigerdelta.pdf [Accessed 5th April, 2019]

53. Walsh, M.T., 2009. The use of wild and cultivated plants as famine foods on Pemba Island, Zanzibar. Etudes Ocean Indien, special issue: Plantes et societies dans l'ocean occidental, 42/43, 217-241. Available online at http://oceanindien.revues.org/793 [Accessed on 3rd June, 2019]

54. Watkiss, P., Pye, S., Hendriksen, G., Maclean, A., Bonjean, M., Shaghude, M., Sheikh, M., and Khamis, Z., 2012. The Economics of Climate Change in Zanzibar. Study Report for the Revolutionary Government of Zanzibar, Climate Change Committee. Available online at http://www.economics-of-cc-inzanzibar.org/reportsandpublications.html. [Accessed 2nd November 2019]

55. Yadav, P., Sharma, A.K. 2015.Agriculture credit in developing economies: A review of relevant literature. Int. J. Econ. Financ.7: 219.

\section{Figures}

\section{Figure 1}

Location of the study areas. Left is Pemba and right is Unguja Island 


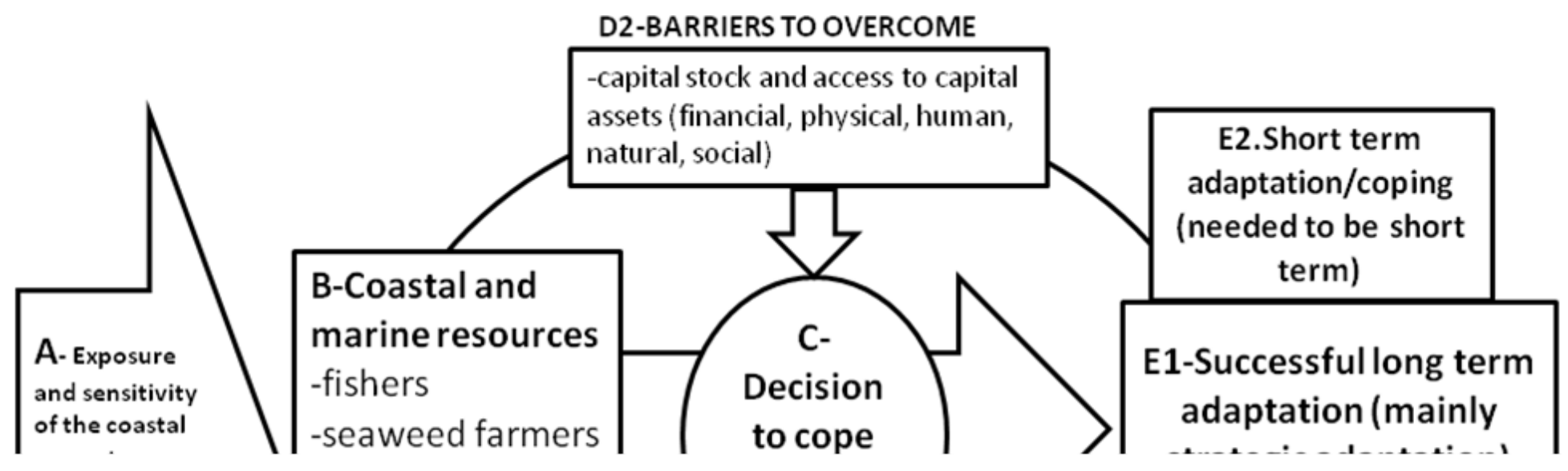

Figure 2

Adaptation framework 